WellBeing International

WBI Studies Repository

$1-2008$

\title{
Parent-Offspring Resource Allocation in Domestic Pigs
}

\author{
Anna Drake \\ University of British Columbia \\ David Fraser \\ University of British Columbia \\ Daniel M. Weary \\ University of British Columbia
}

Follow this and additional works at: https://www.wellbeingintlstudiesrepository.org/feebeh

Part of the Animal Studies Commons, Behavior and Ethology Commons, and the Comparative Psychology Commons

\section{Recommended Citation}

Drake, A., Fraser, D., \& Weary, D. M. (2008). Parent-offspring resource allocation in domestic pigs.

Behavioral Ecology and Sociobiology, 62(3), 309-319.

This material is brought to you for free and open access by WellBeing International. It has been accepted for inclusion by an authorized administrator of the WBI Studies Repository. For more information, please contact wbisr-info@wellbeingintl.org.

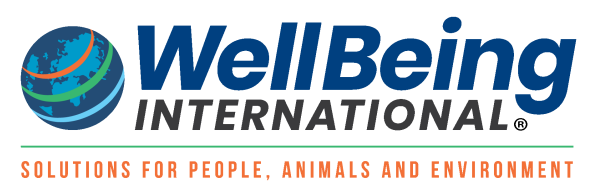




\title{
Parent-Offspring Resource Allocation in Domestic Pigs
}

\author{
Anna Drake, David Fraser, Daniel M. Weary \\ University of British Columbia
}

\begin{abstract}
KEYWORDS
Sus scrofa, parent-offspring conflict, sibling competition, honest signaling, maternal care, suckling
\end{abstract}

\begin{abstract}
Behavioural research on domestic pigs has included parent-offspring conflict, sibling competition, and the use of signals which influence resource allocation. In this paper, we review key sow-piglet behavioural studies and discuss their relevance to resource allocation theory. Sibling competition begins in the uterus and continues after birth, as piglets compete directly for access to the sow's teats. This competition is made more severe by a unique dentition, which newborn piglets use to lacerate the faces of siblings during teat disputes. Competition often leads to the death of some littermates, especially those of low birth weight. Piglets also compete indirectly for milk, apparently by stimulating milk production at the teats that they habitually use at the expense of milk production by other teats. The complex nursing behavior of the sow appears designed to prevent the more vigorous piglets from monopolizing the milk. Sows give vocal signals which both attract piglets to suckle and synchronize their behavior during nursing episodes. Piglets give loud vocal signals when separated from the sow; calls which vary in intensity and appear to be honest signals of need. Udder massage by piglets may also serve as an honest signal of need. Parent-offspring conflict has been demonstrated experimentally in pigs. Specifically, when given the opportunity to control contact with their piglets, sows nurse less frequently, provide less milk, and lose less weight during lactation than sows that cannot control their level of contact. Because of this interesting natural history and because they are so amenable to experimentation, domestic pigs provide a rich system for testing ideas drawn from resource allocation theory.
\end{abstract}

\section{Introduction}

Modem western breeds of swine, descended from the Eurasian wild boar (Sus scrofa), were first domesticated 5,000-10,000 years ago (Zeuner 1963). The dynamics of sow-piglet and piglet-piglet interactions have been studied extensively partly because of the species' economic importance. As we illustrate below, the biology of the pig makes it a particularly interesting subject for understanding resource allocation between parents and young and among siblings-behavior that incorporates parentoffspring conflict and sibling rivalry. This paper is part of a series of reviews on parent-offspring conflict (see Hudson and Trillmich 2007). In this paper, we review key sow-piglet behavioral studies and discuss their relevance to resource allocation theory. Much of the original research was first published in 
agricultural journals and may not be well known to behavioral ecologists. We begin with a brief review of the natural history of the pig, as this provides important context for what is to follow.

\section{Natural history of the pig}

Although domestic pigs show some divergence from their ancestral form and life history patterns, this heritage is still reflected in many of the behaviors seen today. Pigs are members of the order Artiodactyla (even-toed ungulates) and the suborder Suina which includes peccaries and hippopotami (Graves 1984). In the wild, S. scrofa typically live in social groups of two to five related females and their immature offspring (Dardaillon 1988; Graves 1984). Mature males are solitary, associating only with sexually receptive females (Graves 1984). A number of observational studies indicate that estrus is strongly linked to food availability and sow condition (Graves 1984; Baber and Coblentz 1986).

Wild pigs are promiscuous, and although males actively compete for access to females (Graves 1984), behaviors such as mate guarding or harem formation are not evident. Domestic sows readily mate with different males and often produce litters of mixed paternity. The domestic sow's long estrous period (2-3 days), combined with the relatively large volume of semen produced by boars, suggests that sperm competition may be important (Fraser et al. 1995a).

Wild sows have, on average, only four to five piglets per year (Mauget 1982), but litter size can vary from 4 to 13 (Mohr 1960 cited in Algers and Jensen 1985), with one or two litters per year depending on conditions (Mauget 1981). A pregnant sow will leave her social group a day or two before giving birth, find a suitable farrowing site and construct an elaborate nest of branches and grass in a depression that she has rooted out (Graves 1984). When her offspring are approximately 10 days old, the sow will rejoin the group (Dardaillon 1988). Once within the group, lactating sows will often tolerate the suckling of offspring that are not their own (Eisenberg and Lockhart 1972; Newberry and Wood-Gush 1985); thus, pigs are one of many mammalian species that provide some degree of care to non-descendant young (see for example, Jennions and Macdonald 1994). Group living likely offers increased thermoregulation (Bautista et al. 2007) and vigilance and allows sows to spend more time foraging without neglecting the defense of their young (Mauget 1981; Graves 1984). Given that group members are related, the cost of milk "theft" may be mitigated by inclusive fitness. Offspring are weaned at 2-3 months of age (Newberry and WoodGush 1985) and disperse when sexually mature (7-8 months old) or when the sow is ready to farrow again (Conley et al. 1972 cited in Graves 1984).

Domestic pig breeds retain many of the behavior patterns shown by the wild species. When allowed to become feral or when placed in free-range conditions, domestic pigs will rapidly revert to ancestral social and behavioral patterns. Sows will form groups, and pregnant sows will leave their group to build a nest and farrow (Csermely 1994; Jensen 1986). In fact, sows will perform nest-building movements even when confined indoors on concrete flooring. Unlike wild boar, domestic pigs may breed throughout the year with no distinct mating season (Peine and Farmer 1990). While broad patterns of behavior remain intact, artificial selection has led to larger body size, increased number of teats, and larger more rapidly growing litters in modem breeds.

\section{Parent-offspring conflict}

As explained by Trivers (1974), parents do not always share the same interests as their developing offspring, and conflict between parents and offspring can occur over the amount and duration of parental care. We would expect parent-offspring conflict to occur whenever the level of post-natal investment that maximizes the parents' fitness is lower than that which maximizes the fitness of each offspring. 
Generally, there is a trade-off between the number and the quality of young produced in a single reproductive event (Campbell 1996). Large clutch sizes and small young are typical of animals whose offspring experience high mortality rates (Campbell 1996). Domestic pigs fit this "low investment, high volume" pattern quite neatly. Unlike most ungulates, they produce multiple young per parturition, and piglets are born small (roughly $0.5 \%$ of their mother's body weight; Fraser and Thompson 1991), with no subcutaneous fat and very little body fat in total (1-2\% of their body weight; Herpin and Le Dividich 1995). The energy available to piglets at birth is remarkably low: calculations derived from glycogen and fat stores indicate that per unit of body weight, a piglet has only $66 \%$ of the energy stores available to a newborn lamb and 30\% of that available to a calf (Herpin and Le Dividich 1995). Correspondingly, piglet mortality rates are high: in domestic breeds, an average of $12 \%$ of piglets born alive die before weaning (Varley 1995), with greater losses in free-ranging environments (cited in Andersen et al. 2005). Studies of wild boar suggest a pre-weaning mortality of $21 \%$ (derived from Femandez-Liario and Mateos-Quesada 2005) in nature and 30--40\% when farmed (cited in Andersen et al. 2005). Feral piglets can experience mortality above $50 \%$ within the first 2 to 4 months of life (Baber and Coblentz 1986).

Trivers (1974) highlighted weaning as the period when the divergent interests of parent and young are perhaps the most visible. However, conflict over the distribution of resources between parent and young should, in theory, be present throughout their association, including during pregnancy and early post-natal development. Sows invest relatively little energy per piglet during pre-natal development, so the most energetically efficient time for brood reduction is likely shortly after birth. Significant neonatal mortality may actually improve a sow's overall fitness by enabling her to invest more resources in her remaining young while maintaining her own body condition. Thus, we may expect that conflict of interest should be high soon after birth, with the sow's average investment being below each piglet's ideal. However, as total investment by the sow accumulates over time, there should be a point when the sow's fitness is best served by ensuring that her current young reach independence. During this period, sow-piglet interests should be most closely aligned, but once piglets are capable of independent survival, interests will again diverge and weaning conflict should ensue.

The amount of suckling a sow allows will directly affect her piglets' growth and condition. However, high milk production also results in high energetic demand on the sow and can lead to substantial weight loss during lactation (see below). Thus, conflict should be visible through differences in nursing frequency, piglet weight gain and sow weight loss when rearing systems give greater control to one party or the other. Some estimate of the level of conflict between sows and piglets can be made by comparing behavior in free-range systems (where sows can actively avoid the piglets) versus confinement systems (where they cannot). Controlled experiments can provide more specific comparisons.

When pigs are housed in large outdoor enclosures, sows can exert some control over their level of contact with their young. In these systems, sows appear to allow piglets to suckle frequently (and for as long as they wish) during the first $48 \mathrm{~h}$ after farrowing but to then progressively reduce nursing frequency and duration through the active termination of nursing bouts (Fig. 1; Csermely 1994; Jensen and Recen 1989). This pattern is similar to that seen in other species (for example: cats, Felis cattus, Schneirla and Rosenblatt 1961; goats, Capra aegagrus hircus, Alley et al. 1995; rhesus macaques, Macaca mulatta, Gomendio 1991). By the end of 4 weeks, nursing frequency and sow contact with the litter is substantially reduced and the piglets have begun to consume solid food (Jensen 1988; Jensen and Recen 1989; Newberry and Wood-Gush 1985). Interactions and nursing continue to decline until the piglets are fully weaned at 12-16 weeks of age (Jensen 1988; Jensen and Recen 1989; Newberry and Wood-Gush 1985).

By contrast, in most commercial farrowing systems, lactating sows have little control over contact with their piglets, as they are typically housed in "farrowing crates". These crates are restrictive enclosures for 
the sow designed to reduce the chance of her accidentally crushing her young. The crate prevents the sow from walking or turning around, and thus, from moving away from the litter. Piglets spend more time nosing and massaging the udder of sows in crates than of sows with greater freedom (De Passille and Robert 1989; Rantzer et al. 1995). Sows in crates limit the piglets' suckling in the few ways possible: by standing or sitting and by spending more time resting on their sternum (thus, covering the teats) than free-ranging sows (De Passille and Robert 1989; Rantzer et al. 1995). These avoidance tactics are likely limited in their effectiveness and, as a result, we would expect nursing rates, piglet weight gain, and sow weight loss to be higher in such confinement systems.

Fig. 1. Percentage of nursing episodes terminated by the sow during the first 8 days after birth in a freerange system (adapted from Csermely 1994)

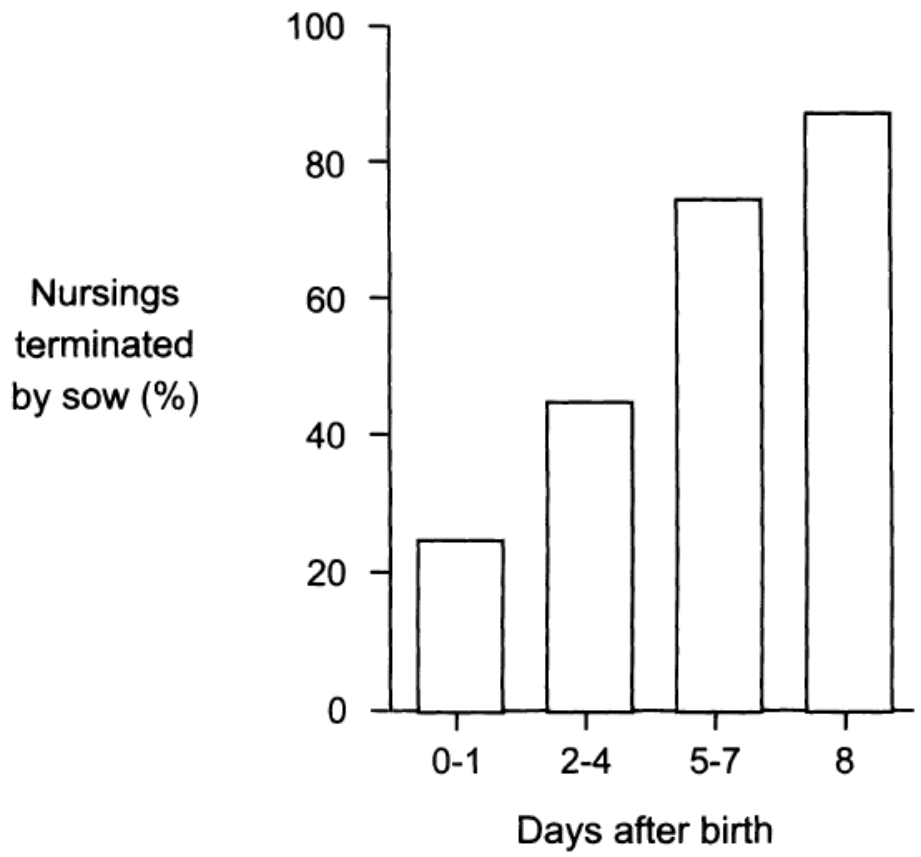

Variation in food availability, temperature, and other factors limit the value of comparisons between outdoor free-range and indoor intensive rearing systems. In a more controlled comparison, Pajor (1998) modified standard indoor housing to create an area where sows could get away from their litters by stepping over a partition. To increase the cost of maternal care, sows were given a diet that was low in the limiting amino acid lysine. When compared to sows that could not escape from their piglets, sows with access to a "get-away" area lost $37 \%$ less weight, nursed $44 \%$ less frequently during the fifth week of lactation, and were able to rebreed slightly earlier (Pajor 1998). Although piglets of these "get-away" sows presumably consumed less milk, they were able to maintain normal weight gains by consuming more of the highly palatable solid feed that was available ad libitum (Pajor 1998). The limited supply of essential nutrients for sows in this study likely mimics natural conditions where sows face some form of nutritional limitation. For example, Baber and Coblentz (1986) reported that the body condition of lactating feral sows declined in the summer when nutrition was poor and that "[m]any of these animals appeared unable to sustain lactation for 3 to 4 months ... [meaning that] piglets were probably weaned earlier and in poorer condition ...."

Similar studies using well-balanced sow diets have resulted in similar behavior, but less effect on sow weight loss and return to estrus. Sows that were able to get away from their young significantly reduced their nursing frequency (Pajor et al. 2002; Weary et al. 2002; Fig. 2), but did not differ from the controls in 
post-lactation weight or time to estrus apparently because confined sows compensated for their higher nursing frequency by consuming more feed (Pajor et al. 2002; Weary et al. 2002). Piglets compensated for the reduced nursing frequency in "get away" housing by increasing their intake of solid feed before weaning (Pajor et al. 2002; Weary et al. 2002).

As in free-ranging conditions, sows in "get away" housing increased the time they spent away from their litter and reduced their nursing frequency over the course of lactation (Pajor et al. 2002; Pitts et al. 2002; Weary et al. 2002). Sows that were relatively thin at parturition, and those that gave birth to larger litters and heavier young, tended to make greater use of the get-away area and to nurse less frequently (Pitts et al. 2002).

To help separate the effects of sow and piglet behavior, one study provided get-away access for the piglets but kept sows in conventional farrowing crates (Weary et al. 1999). Under these conditions, sows were unable to get away, but piglets from multiple litters were able to use a common area where they had access to solid food. Piglets kept in this condition spent more time away from the sow than those kept in conventional housing, and this increased time away translated into a slightly reduced nursing frequency. However, as would be expected in a situation where piglets maintain control over access to the sow, they suffered no ill effects from these behavioral changes; piglets gained body weight at the same rate as controls and did not show the increased intake of solid food observed in experiments that allowed the sows to control the level of interaction.

Fig. 2. The number of nursing episodes per day in relation to piglet age for sows that were confined with their young (empty square) and those that could leave (black diamond; adapted from Weary et al. 2002)

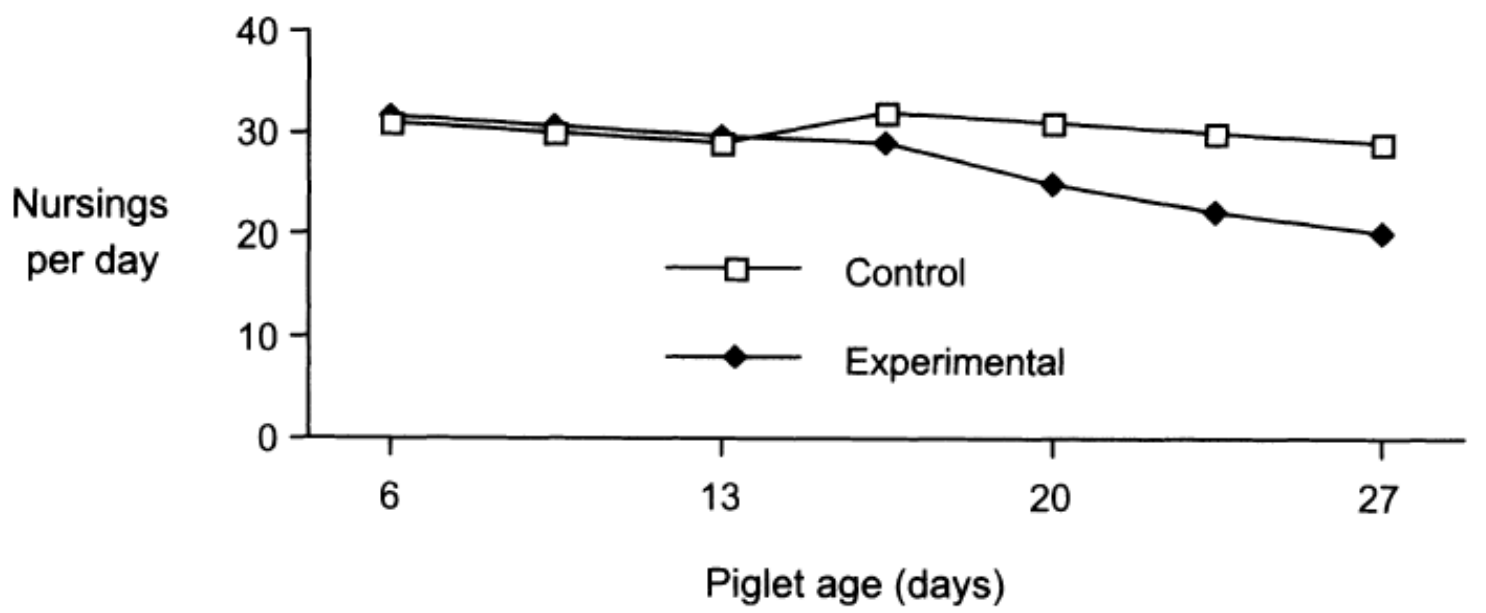

\section{Sibling rivalry and siblicide}

Where parental resources are limited, we can expect siblings to compete because each sibling derives a greater fitness benefit from the parental investment that it receives than from the parental investment received by other members of the litter (Godfray 1995; Hudson and Trillmich 2007; Mock 2004; Trivers 1974). This conflict of interest sets the stage for both direct and indirect competition among littermates. Direct competition takes the form of fighting for access to the udder. Indirect competition occurs through the modification of the uterine environment and through unequal extraction of resources from the sow, both from the placenta before birth and from the mammary glands after. 
Competition among piglets begins in the uterus. During estrus, sows ovulate the majority of their follicles over a short period of time and then a few additional follicles over an extended period (Pope et al. 1990). This creates differential development among embryos, with the more developed majority having a survival advantage over the less developed (but equally viable) minority (Pope et al. 1990). While the exact cause of higher mortality rates in the less developed embryos is unknown, the increasing synthesis of estradiol by advanced embryos appears to be involved. This steroid hormone modifies the uterine environment and triggers the release of complex uterine secretions (including growth factors, calcium, and prostaglandins) which may place less developed embryos at a disadvantage (Pope et al. 1990). Administration of estrogen during early development is directly linked to embryonic death (Gries et al. 1989).

There is also competition over space. Embryos require approximately $20 \mathrm{~cm}$ of the sow's uterine length to survive (Dziuk 1985) and $30 \mathrm{~cm}$ to develop fully (Dziuk 1992). Embryo density is greatest in the central portion of the uterus and decreases toward the tips of each uterine horn. According to Dziuk (1992), 7\% of embryos carried in the crowded central area of the uterus die early in the pregnancy. Moreover, because the middle portions of the uterine horns do not provide enough space to support maximum growth, $7 \%$ of surviving piglets from this region have unusually low birth weights (Dziuk 1992). This body size difference at birth has implications for later growth and survival.

Direct neonatal piglet competition centers on access to teats. Piglets are precocial and capable of active competition within minutes of birth. Shortly after birth, some piglets will locate and retain possession of a teat. Those who fail to do this will shift from place to place along the udder, initiating fights and attempting to displace other littermates (Scheel et al. 1977). Displaced piglets face a double cost: they expend energy in finding and obtaining a teat and they often fail to obtain colostrum and milk during early nursing episodes (Scheel et al. 1977). Approximately 43\% of piglet deaths result from starvation or the crushing of weakened malnourished young (English and Smith 1975), and 80\% of neonatal deaths occur within the first 3 or 4 days after birth (Svendsen 1992). Competition, rather than a general inability to thrive, appears to be the cause of many starvation deaths (English and Smith 1975; Hartsock and Graves 1976; Fraser et al. 1995b). When Leece (1971) identified low-birth-weight piglets (which were assessed as unlikely to survive) and raised them on automatic feeding systems without competition, these piglets grew as quickly and efficiently as other animals.

Under normal conditions, birth weight is a reasonable predictor of survival (Broekman 1985; Pluske et al. 1995; Scheel et al. 1977; Fig. 3). Larger piglets are more resistant to cold (Herpin and Le Dividich 1995) and consume more colostrum (Fraser and Rushen 1992). Heavier piglets also win more fights over access to teats (Scheel et al. 1977), gain more weight (Milligan et al. 2001), and experience lower mortality (Cutler et al. 1999; Tuchscherer et al. 2000).

Early birth may also confer advantages (Tuchscherer et al. 2000). Passive immunity is obtained via immunoglobulins in the colostrum. The concentration of these proteins declines as much as $50 \%$ during the first few hours of nursing; hence, late born piglets may receive less than their siblings (Bourne 1969; De Passille et al. 1988). Colostrum is also an important source of energy for the newborn, and supports the maintenance of body temperature (Herpin and Le Dividich 1995). Newborn piglets sample an average of seven different teats within the first $8 \mathrm{~h}$ after birth (De Passille and Rushen 1989), and this behavior likely helps them maximize their intake of colostrum (De Passille et al. 1988). Each teat, however, supplies only 50-100 $\mathrm{ml}$ before intra-mammary pressure is reduced to the point that withdrawal becomes difficult for the neonate (Fraser 1984). This pressure can rebuild within 10 to 20 min through the release of oxytocin (Fraser 1984), but available colostrum is quickly depleted by the piglets already occupying the teats. As a result, late born young may have lower colostrum intake than earlier born siblings. Simulated 
birth order offers some support for this: piglets introduced to the udder at $3 \mathrm{~h}$ after the start of farrowing had less colostrum intake than those introduced at $2 \mathrm{~h}$ (Fraser and Rushen 1992).

Fig. 3. The percentage of piglets born in different birth weight classes and the percentage that died before weaning. From a study of more than 7,000 piglets by Broekman (1985)

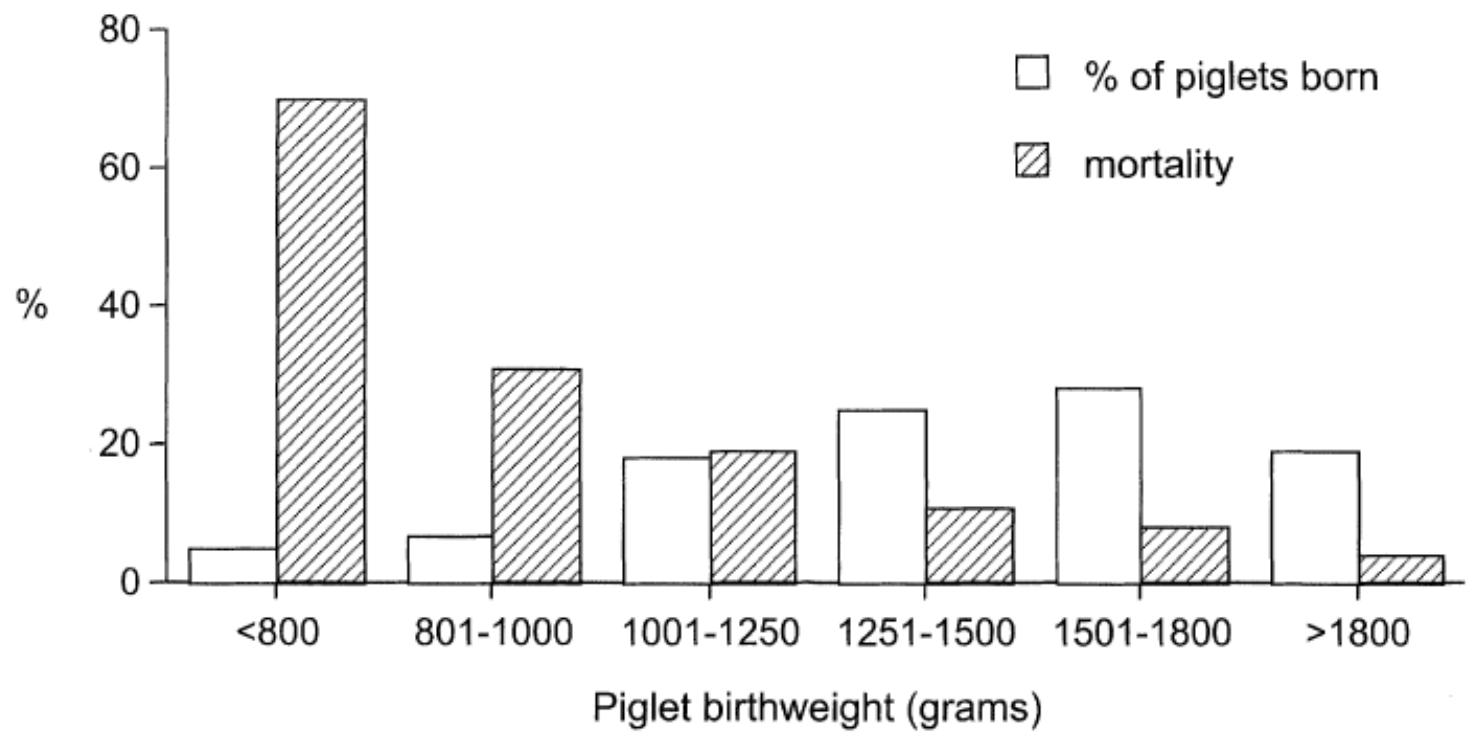

Competition among littermates is made more dangerous for the combatants by the peculiar dentition of the newborn piglet (Fig. 4). Piglets are born with their deciduous canines and third incisors fully erupted and angled in such a way that the sideways biting action that piglets use to displace siblings from teats can result in significant facial lacerations (Fraser 1975, 1990; Fraser and Thompson 1991; Weary and Fraser 1999). These weapons appear to function solely in early intra-litter competition, as growth of the jaw and eruption of other teeth render them insignificant at other ages. To prevent injuries, farmers commonly clip the teeth soon after birth. However, Fraser and Thompson (1991) showed that in large litters, piglets with unclipped teeth gained more weight than similar littermates with clipped teeth, and that unclipped teeth led to a significant improvement in the survival of piglets of low birth weight.

Piglets generally settle into an orderly feeding pattern during their first week (Fraser 1975; Hemsworth et al. 1976), with little overt competition at the udder. This reduction in open conflict is the result of a stable system of teat preference whereby piglets consistently return to the same teat or same pair of teats at successive suckling episodes (Donald 1937; Fraser 1975; Hemsworth et al. 1976). The teat that becomes the piglet's permanent suckling position tends to be the one that the piglet was able defend from rivals during the first $6 \mathrm{~h}$ after birth (Scheel et al. 1977).

Not all teats are equal. During the first hours after birth, when still squabbling over position, piglets show a strong attraction to the anterior portion of the udder (Donald 1937; Scheel et al. 1977; Jeppesen 1982; but see Fernandez-Llario and Mateos-Quesada 2005). Previous authors have speculated on proximate reasons why this may be so: that the pattern of hair on the sow's belly directs the piglet in a posterior-toanterior direction (McBride 1963; Rohde Parfet and Gonyou 1991), and an attraction to the sow's voice also draws piglets forward (Jeppesen 1982). Ultimately, however, there may be an advantage to claiming anterior teats. Piglets help to initiate nursing bouts and stimulate milk ejection by nuzzling the sow's udder, and anterior teats are known to be more sensitive to this massage (Fraser 1973). There is also evidence that anterior teats produce slightly more milk. For example, Gill and Thomson (1956) estimated 
that over a 56-day lactation period, there was an average 15\% difference in piglet weight gains along the udder, with piglets using the front four teats consuming more milk during each nursing than those using the back four. Similarly, pigs on anterior teats show greater overall growth (Fraser et al. 1979). Both of these comparisons, however, are multiply confounded by variations in suckling strength and initial body size. Specifically, piglets that are larger at birth may be better able to maintain ownership of an anterior teat (where competition is more severe); greater initial body size may reflect greater potential for growth; and larger body size and suckling strength may induce greater milk production through increased demand as discussed below. Where differences in teats exist, they may become important in the subtle indirect competition that occurs throughout lactation.

Fig. 4. The teeth of domestic pigs at three different ages showing the changing orientation of the third incisor (arrow) during growth: from a pronounced canine-like position at birth (top jaw), to a more forward orientation at an age when the pig, under natural conditions, would be almost entirely weaned (bottom jaw; from Fraser 1990)

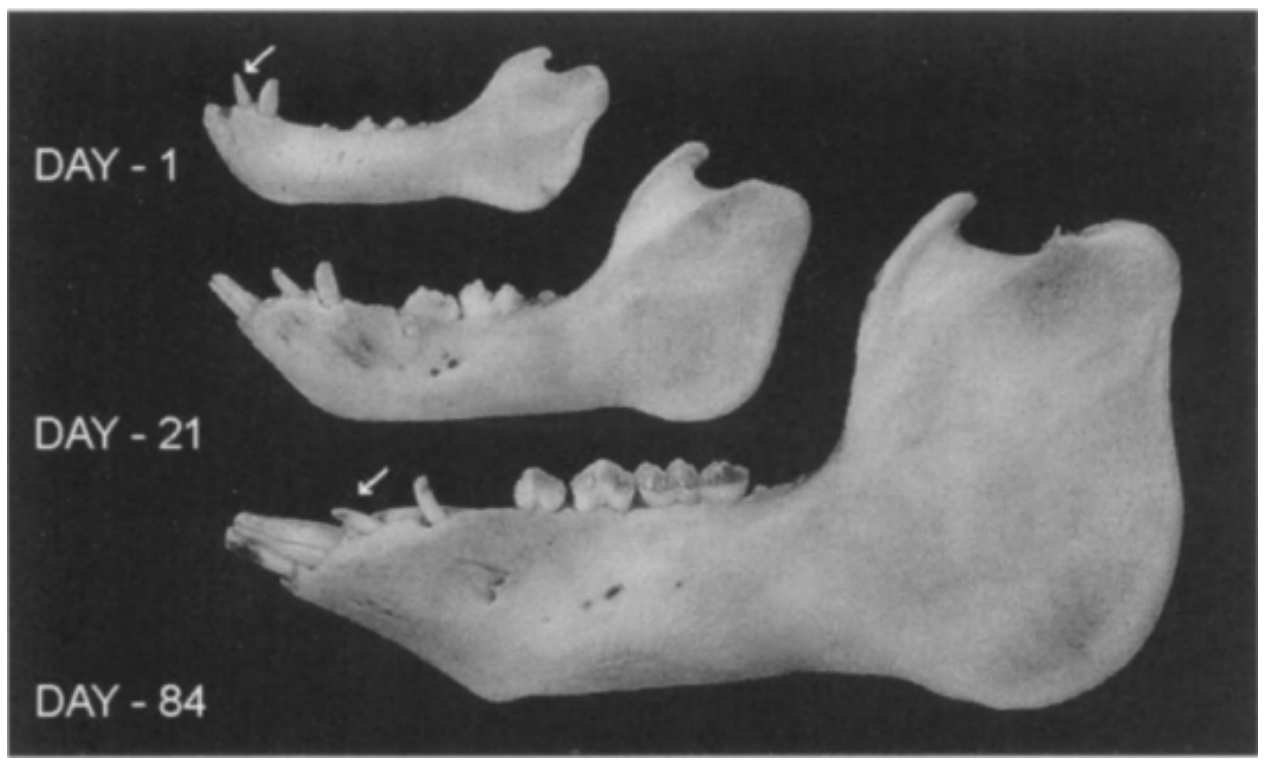

Indirect competition among littermates is illustrated by cross-fostering experiments that impose experimental control on variation in piglet body weights. Piglets of medium birth weight assigned to litters with heavier foster siblings gain less weight than similar piglets assigned to litters with lighter foster siblings (Fig. 5). This suggests that littermates indirectly affect each other's milk intake (Fraser 1990; Fraser et al. 1979). This indirect competition could occur in various ways. Larger, more vigorous individuals may be able to drain their teat more efficiently, thus, potentially stimulating higher production in that section of the udder (Fraser 1990). Alternatively, by vigorous massage of its teat, a piglet may be able to stimulate blood flow, and hence, attract blood-borne nutrients and hormones to the mammary tissue in that area (Algers 1993; Algers and Jensen 1985; Fraser 1984). Within a week or two of birth, a pattern emerges whereby growth rate becomes increasingly a fixed percentage of body weight (Thompson and Fraser 1986). In this way, differences established within the first 1-2 weeks are perpetuated and amplified over the rest of the lactation (Thompson and Fraser 1986; Thompson and Fraser 1988).

Taken together, the variation in body weight, the overt competition, and the high early mortality present a situation similar to that found in some species of birds where asynchronous hatch times result in body size differences within the brood (Fraser et al. 1995a). In these species, sibling rivalry results in the death of some siblings. This can occur directly through overt aggression as in the swallow-tailed kite (Elanoides 
forficatus; Gerhardt et al. 1997) and the lesser spotted eagle (Aquila pomarina; Meyburg 1974), or indirectly through aggression and intimidation, ultimately leading to starvation, as in goshawks (Accipiter gentilis; Schnell 1958) and great egrets (Casmerodius albus; Mock 1987).

Fig. 5. Evidence of indirect competition among littermate piglets. Piglets from pairs of litters born on the same day were ranked from the $A$ (heaviest) to the $D$ (lightest) quartile of the combined litter. One sow raised quartiles $A$ and $B$, while the other raised quartiles $C$ and $D$. The $C$ piglets began lighter than the $B$ piglets but had the advantage of being the largest individuals in the re-assigned litters, whereas the $B$ piglets were the smallest in theirs. Under these conditions, the $C$ piglets gained more weight than the $B$ s by 21 days of age (adapted from Fraser et al. 1979)

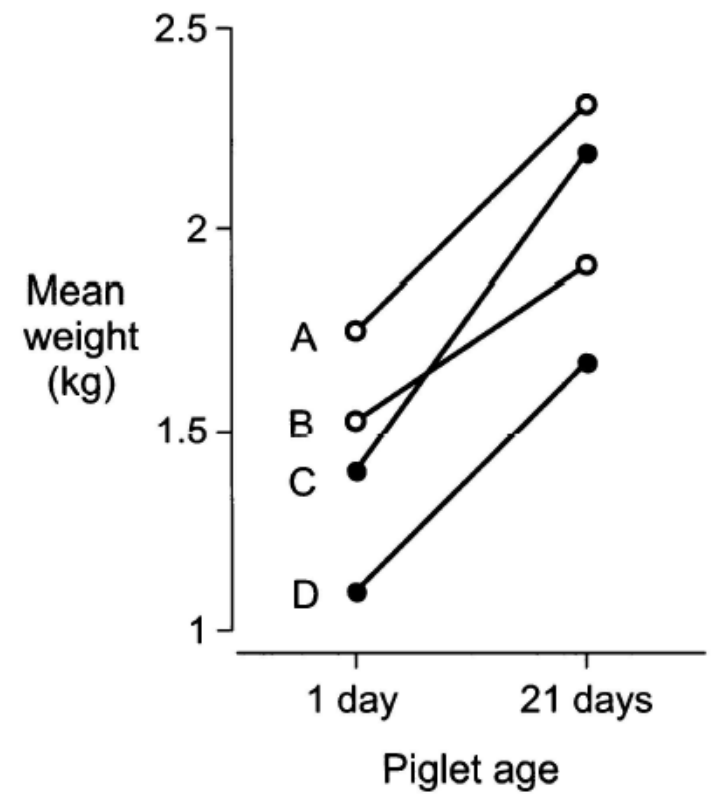

Sibling rivalry leading to death is so common in these species that it would appear to be a reproductive strategy. In some cases, extra offspring may act as insurance against loss of young through accident or predation (Forbes 1990). In environments where resources are variable and the cost of producing extra offspring is small, it may be advantageous for the parent to produce some low-investment "spare" young (Lack 1947; Mock 2004; Trillmich and Wolf 2007; White 2007). Should resources be plentiful, all of the young survive and the parent derives an extra benefit at minimal cost (Mock 2004; Mock and Parker 1998). However, should resources be limited, competition between siblings (triggered by hunger) reduces the brood to the number that can be provided for (Mock 1984). In such "facultative siblicide" systems, there tends to be a body size difference among offspring. This variation may provide a selective advantage such that the larger young (which have received more investment) are not harmed by the presence of the smaller low-investment young in times of shortage (Mock 1984; Trillmich and Wolf 2007). From this perspective, some of the early piglet mortality might be viewed as facultative siblicide (Fraser 1990) and pigs, like spotted hyenas (Golla et al. 1999; Smale et al. 1999; Hofer and East 1997; White 2007), may be considered one of only a few species of mammal that follow this strategy.

\section{Signals of need}

Sow-piglet communication makes use of physical, auditory, and olfactory signals (Rohde Parfet and Gonyou 1991). Most studies center on vocal and physical interactions, as these are the easiest to measure. Sow-piglet interactions are highly vocal. For example, sows change their grunt rate in a way 
that signals the imminent ejection of milk (Fraser 1980), and background noise that masks these vocalizations can severely disrupt normal suckling behavior (Algers and Jensen 1985). Moreover, piglets call when hungry (Algers and Jensen 1985) or when isolated from the sow (Weary and Fraser 1995) and sometimes scream while competing at the udder (Appleby et al. 1999). Studies also indicate that a sow can differentiate between the vocalizations of her own offspring and those of others (Illmann et al. 2002). Physical communication between sows and piglets involves, most notably, the stimulation of the teat before and after milk ejection. Sustained coordinated massage of the udder is necessary to trigger milk ejection in the sow (Fraser 1980), and massage after milk ejection is an energetically costly behavior which may influence milk production for subsequent nursing episodes (Algers and Jensen 1985, 1991; Gill and Thomson 1956; Spinka and Algers 1995). Hormonal studies indicate a quantitative relationship between udder massage and the release of prolactin, glucagon, and vasoactive intestinal polypeptide, suggesting that the sow's metabolism is altered by the piglets' behavior (Algers 1993; Algers et al. 1991).

Where parent-offspring conflict exists over resource allocation, we might expect an escalation of signaling because a strong signal by the young could elicit a response from the parent that more closely matches their optimal level of investment, while the parent might become decreasingly responsive to such signals to maintain investment closer to their own optimum (Godfray 1991). "Honest" signaling between parent and offspring is expected to evolve either where there is no conflict of interest between the sender and the receiver or where conflict of interest exists but there are costs to signaling that mitigate any advantage obtained through dishonesty. In the first scenario, where interests are mutual, we would expect communication between parties to convey honest information and for this information to be sent at the minimum level required to convey it (Maynard Smith 1994). In the second scenario, signals of need are kept honest only if they incur a fitness cost that limits escalation over time (Kilner and Johnstone 1997; Godfray and Johnstone 2000). Honest signaling theory, as it pertains to offspring solicitation, makes three predictions: (1) that signal intensity will increase with offspring need, (2) that parents should respond to, or provision young, in relation to signal intensity, and (3) that the signal should be costly (Kilner and Johnstone 1997).

In pigs, the communication of milk availability by the sow could be considered a signal where both the parent's and offspring's interests align: the sow is motivated to be suckled, and the piglets are motivated to feed. Given this shared interest, we would expect the energetic expenditure of the sow on this signal to be low (as predicted by Maynard Smith 1994), and yet, the response by the piglets to be high. This appears to be the case; moreover, this signal is part of a system which appears to regulate the level of sibling competition for milk.

As noted above, pigs are unusual animals in that they give birth to litters of many young (like most rodents and carnivores), yet the young are behaviorally precocious (like most other ungulates), and hence capable of competing for access to the udder (see also Fey and Trillmich 2007). Several features of the sow's nursing system seem designed to prevent the more capable piglets from monopolizing the milk (Fraser 1980). First, the sow requires roughly a minute or more of vigorous stimulation of the udder before ejecting milk. Hence, milk ejection is unlikely to occur unless most of the piglets have assembled. Second, the sow vocalizes throughout this stimulation, and the calls attract any missing piglets to the udder. Third, the milk ejection is very brief, typically lasting only 10 to $20 \mathrm{~s}$ and, because the teat has no anatomical cistern, piglets can withdraw milk only during this period. Piglets need to be sucking throughout the ejection to maximize milk intake; fighting during this time would mean lost milk. The sow signals the imminent arrival of milk by a sharp increase in her rate of grunting at the time oxytocin is released from the pituitary gland (Ellendorff et al. 1982; Fraser 1980). The peptide takes about $20 \mathrm{~s}$ to reach the udder; hence, the increase in grunting comes about $20 \mathrm{~s}$ before the milk (Fig. 6; Whittemore and Fraser 1974). Once piglets are a few days old, they appear to hear this signal and switch from 
massaging the udder to sucking on the teats, and thus, are ready to consume the milk as soon as the ejection begins. In noisy environments, the synchronous change from massage to suckling breaks down, supporting the idea that the behavioral trigger is auditory (Algers and Jensen 1985).

Fig. 6. Two examples of nursing bouts showing the relationship between sow grunt rate, piglet behavior, and milk ejection. Sow grunt rate rapidly increases just before milk ejection, coinciding with the release of oxytocin from the brain. Piglets switch from massaging the udder to suckling when the sow's grunt rate increases. Active rapid suckling (between the two vertical lines) occurs approximately $20 \mathrm{~s}$ after the grunt rate peak, the time that it takes for the hormone to reach the mammaries and trigger milk ejection (adapted from Whittemore and Fraser 1974)

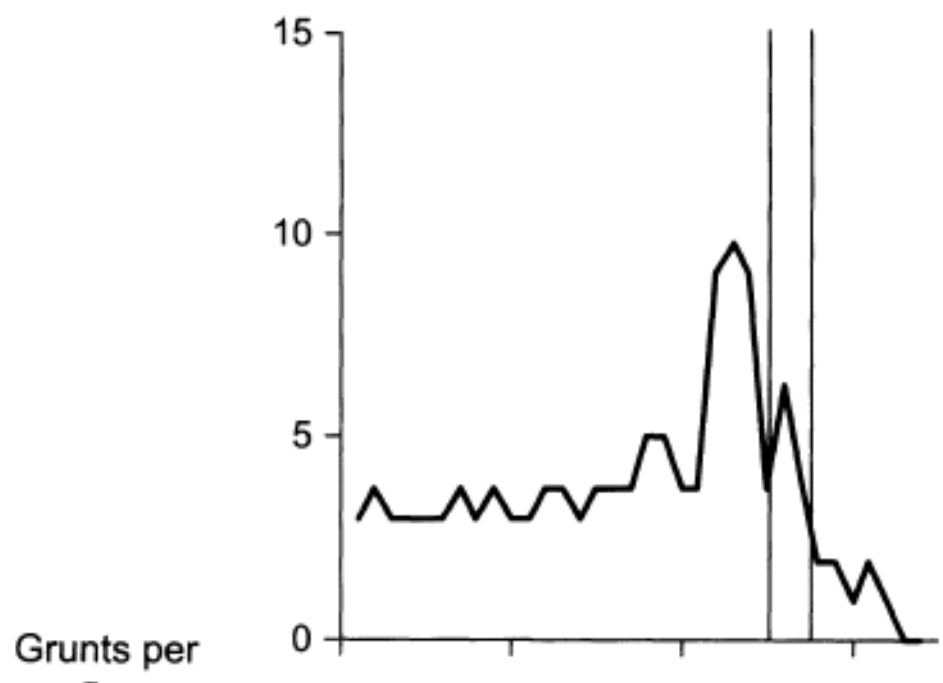

$5 \mathrm{~s}$

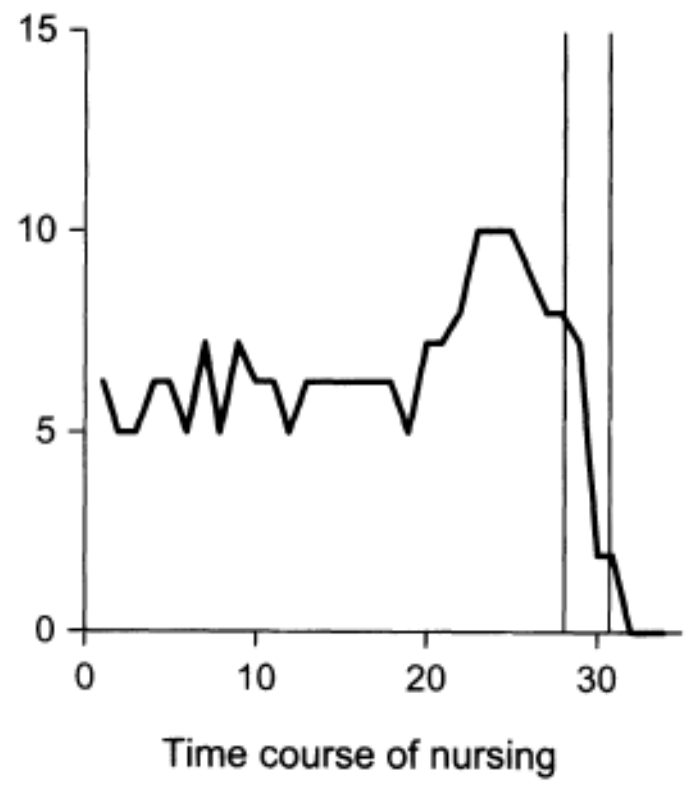

The calls uttered by piglets when they have been separated from the sow may be better understood using honest signaling theory. The first key prediction from this theory (that the level of signaling is positively associated with level of need) has been borne out in experimental studies. For example, Weary and Fraser (1995) compared the separation calls of piglets that varied in condition. Consistent with predictions, "non-thriving" (the lightest and most slowly gaining piglets) and "unfed" piglets (separated 
from the sow slightly earlier, and as a result, having missed the most recent nursing bout) vocalized more than their "thriving" and "fed" littermates when removed from the sow. Consistent with the second prediction (that parental response will vary in relation to signal intensity), sows exhibited a stronger and more rapid response to the longer higher pitched calls of needy young. When recordings of piglet vocalizations were played back to them, sows vocalized more themselves, moved around in their pen more, and spent more time near the playback speaker when they heard the calls of "needy" piglets than when they heard "non-needy" piglets (Weary et al. 1996).

Teat massage by piglets may also be an honest signal of need (Jensen et al. 1998). In addition to massaging the teats before milk ejection, apparently to induce oxytocin secretion, piglets also massage the teats after the ejection for up to 15 min although no more milk is obtained during this massage (Jensen et al. 1998). Final massage may ensure future milk production (i.e., massage effort may be positively associated with food intake). Algers and Jensen (1985) suggest that the final massage may act as a means for piglets to "order" the volume of their future meals and for sows to adjust lactation according to brood size. In particular, massage performed after milk ejection may help stimulate later milk production at the teat by increasing blood flow to the mammary tissue and by stimulating the release of hormones that affect lactation (Algers 1993; Algers and Jensen 1985; Algers et al. 1991). Spinka and Algers (1995) offer some support for this hypothesis, with the duration of final massage being positively correlated to future total milk transfer. Consistent with honest signaling theory, piglets that were prevented from feeding for one milk ejection massaged more intensely and for a longer time afterwards than did those that had fed and those that had received supplemental milk (Jensen et al. 1998).

The fitness costs associated with these signals have not been studied. Both teat massage and calling likely involve some energetic costs. These costs could have fitness consequences especially for newborn piglets with limited energy reserves. Vocal signals could also involve additional costs, in particular attracting the attention of potential predators. Future work needs to address these costs and determine how they vary with piglet condition. In particular, we expect that the fitness costs of signaling may actually be less for those piglets in better condition (e.g., with more energy reserves), and that this inequality in the cost of signaling will also affect these behaviors. Signal intensity in systems where there is more than one offspring may be influenced by sibling competition. Offspring in these systems are expected to respond to both their own state and that of their siblings when soliciting resources (Godfray and Johnstone 2000). In light of high levels of sibling conflict, pigs may be an interesting system in which to test this concept.

\section{Conclusions}

Given that pigs have been domesticated for thousands of years, do they remain useful for studying resource allocation theory? Certainly, the behavior of pigs has been modified by domestication. There has undoubtedly been selection for certain behavioral and temperament traits such as tolerance of human presence. Selection for certain other traits has probably been relaxed; for example, with the physical protection offered by modem farrowing environments, selection may no longer favor sows that avoid crushing newborn young. Nonetheless, studies of modem pigs raised in semi-natural conditions (Newberry and Wood-Gush 1985; Jensen 1986, 1988) indicate that the major qualitative elements of parent--offspring behavior seen in wild pigs remain largely intact. Moreover, some natural selection has undoubtedly continued during domestication: In particular, piglets must compete with their littermates and secure resources from the sow if they are to survive and reproduce. Even artificial selection for certain commercially important traits, such as large litter size and rapid growth, has likely tended more to reinforce rather than to counteract the effects of natural selection. In particular, the pig's basic strategy of producing numerous small young which engage in severe sibling competition has obviously been retained and perhaps accentuated by selection for larger litters. In short, then, although there is a need for 
judgment and awareness of the effects that domestication may have had, we consider that domestic pigs, with their complex nursing and suckling behavior and various modes of communication, provide a rich system for the study of parent-offspring behavior and resource allocation among parents and young.

\section{Acknowledgments}

We thank our many colleagues in previous work on resource allocation in pigs, especially Ed Pajor, Don Kramer, and Brian Thompson. The UBC Animal Welfare Program is funded by the Natural Sciences and Engineering Research Council of Canada through the Industrial Research Chair in Animal Welfare, and by contributions from the BC SPCA, the BC Veterinary Medical Association and many others listed at http://www.landfood.ubc.ca/animalwelfare.

\section{References}

Algers B (1993) Nursing in pigs: communicating needs and distributing resources. J Anim Sci 71:28262831

Algers B, Jensen P (1985) Communication during suckling in the domestic pig. Effects of continuous noise. Appl Anim Behav Sci 14:49-61

Algers B, Jensen P (1991) Teat stimulation and milk production in early lactation of sows. Can J Anim Sci $71: 51$

Algers B, Madej A, Rojanasthien S, Uvnas-Moberg K (1991) Quantitative relationships between sucklinginduced teat stimulation and the release of prolactin, gastrin, somatostatin, insulin, glucagon and vasoactive intestinal polypeptide in sows. Vet Res Commun 36:395-407

Alley JC, Fordham RA, Minot EO (1995) Mother-offspring interactions in feral goats-a behavioural perspective of maternal investment. NZ J Zool 22:17-23

Andersen IL, Berg S, Boe KE (2005). Crushing of piglets by the mother sow (Sus scrofa)---purely accidental or a poor mother? Appl Anim Behav Sci 93:229-243

Appleby MC, Weary OM, Alllison AT, Illmann G (1999) Vocal communication in pigs: who are nursing piglets screaming at? Ethology 105:881-892

Baber OW, Coblentz BE (1986) Density, home range, habitat use, and reproduction in feral pigs on Santa Catalina Island. J Mammal 67:512-525

Bautista A, Garcia-Torres E, Martinez-G6mez M, Hudson R (2007) Do newborn domestic rabbits Oryctolagus cuniculus compete for thermally advantageous positions in the litter huddle? Behav Ecol Sociobiol DOI 10.1007/s00265-007-0420-4

Bourne FJ (1969) Studies on the colostral and milk whey proteins in the sow. 2. The effect of delayed suckling on colostrum and milk whey proteins. Anim Prod 11:345-349

Brockman K (1985) Low birthweight causes high mortality. Pigs (February) pp 24-25 
Campbell NA (1996) Biology, 4th edn. Benjamin/Cummings Publishing Company Inc., Menlo Park, California

Conley RH, Henry VG, Matchke GH (1972) European hog research project W-34. Tennessee Game and Fish Commission, Nashville

Csermely $D$ (1994) Maternal behaviour of free-ranging sows during the first 8 days after farrowing. $J$ Ethol 12:53-62

Cutler RS, Fahy VA, Spicer EM, Cronin GM (1999) Preweaning mortality. In: Straw BE, D'Allaire S, Mengeling WL, Taylor DJ (eds) Diseases of swine, 7th edn. Iowa State University Press, Ames, pp 9851002

Dardaillon M (1988) Wild boar social groupings and their seasonal changes in the Carmargue, Southern France. Z Saugetierkd 53:22-30

De Passille AMB, Robert S (1989) Behaviour of lactating sows: influence of stage of lactation and husbandry practices at weaning. Appl Anim Behav Sci 23:315-329

De Passille AMB, Rushen J (1989) Suckling and teat disputes by neonatal piglets. Appl Anim Behav Sci 22:23-38

De Passille AMB, Rushen J, Pelletier G (1988) Suckling behaviour and serum immunoglobulin levels in neonatal piglets. Anim Prod 47:447-456

Donald HP (1937) Suckling and suckling preferences in pigs. Emp J Exp Agric 5:361-368

Dziuk P (1985) Effect of migration, distribution and spacing of pig embryos on pregnancy and fetal survival. J Reprod Fertil (Suppl) 33:57-63

Dziuk P (1992) Survival of peas, peaches and prenatal pigs. Perspect Bioi Med 35:357-360

Eisenberg JF, Lockhart M (1972) An ecological reconnaissance of Wilpattu National Park, Ceylon. Smithsonian contributions to zoology no. 101. Smithsonian Institution Press, Washington

Ellendorff F, Forsling ML, Poulain DA (1982) The milk ejection reflex in the pig. J Physiol 33:577-594

English PR, Smith WJ (1975) Some causes of death in neonatal piglets. Vet Annu 15:95-104

Fernandez-Llario P, Mateos-Quesada P (2005) Udder preference in wild boar piglets. Acta Ethol 8:51-55

Fey K, Trillmich F (2007) Sibling competition in guinea pigs (Cavia aperea f. porcellus): scrambling for mother's teats is stressful. Behav Ecol Sociobiol DOI 10.1007/s00265-007-0419-X

Forbes LS (1990) Insurance offspring and avian clutch size. J Theor Bioi 147:345-359

Fraser D (1973) The nursing and suckling behaviour of pigs. I. The importance of stimulation of the anterior teats. Br Vet J 129:324-336

Fraser D (1975) The 'teat order' of suckling pigs. II. Fighting during suckling and the effects of clipping the eye teeth. J Agric Sci (Camb) 84:393-399 
Fraser D (1980) A review of the behavioural mechanism of milk ejection of the domestic pig. Appl Anim Ethol 6:247-255

Fraser D (1984) The role of behaviour in swine production: a review of research. Appl Anim Ethol 11:317339

Fraser D (1990) Behavioural perspectives on piglet survival. J Reprod Fertil Suppl 40:355-370

Fraser D, Rushen J (1992) Colostrum intake by newborn piglets. Can J Anim Sci 72:1-13

Fraser D, Thompson BK (1991) Armed sibling rivalry among suckling piglets. Behav Ecol Sociobiol 29:915

Fraser D, Thompson BK, Ferguson DK, Darroch RL (1979) The "teat order" of suckling pigs. III. Relation to competition within litters. J Agric Sci (Camb) 92:257-261

Fraser D, Kramer DL, Pajor EA, Weary DM (1995a) Conflict and cooperation: sociobiological principles and the behaviour of pigs. Appl Anim Behav Sci 44:139-157

Fraser D, Phillips PA, Thompson BK, Pajor EA, Weary DM, Braithwaite LA (1995b) Behavioural aspects of piglet survival and growth. In: Varley MA (ed) The neonatal pig: development and survival. CAB International, Oxford, pp 287-312

Gerhardt RP, Dawn MG, Miguel AV (1997) Siblicide in swallow-tailed kites. Wilson Bull 109:112-120

Gill JC, Thomson W (1956) Observations on the behaviour of suckling pigs. Br J Anim Behav 4:46-51

Godfray HJC (1991) Signalling of need by offspring to their parents. Nature 352:328-330

Godfray HCJ (1995) Evolutionary theory of parent-offspring conflict. Nature 376:133-138

Godfray HCJ, Johnstone RA (2000) Begging and bleating: the evolution of parent-offspring signalling. Philos Trans R Soc Lond B 355:1581-1591

Golla W, Hofer H, East ML (1999) Within-litter sibling aggression in spotted hyaenas: effect of maternal nursing, sex and age. Anim Behav 58:715-726

Gomendio M (1991) Parent/offspring conflict and maternal investment in rhesus macaques. Anim Behav 42:993-1005

Graves HB (1984) Behavior and ecology of wild and feral swine (Sus scrofa). J Anim Sci 58:482-492

Gries LK, Geisert RD, Zavy MT, Garrett JE, Morgan GL (1989) Uterine secretory alterations coincident with embryonic mortality in the gilt after exogenous estrogen administration. J Anim Sci 67:276-284

Hartsock TG, Graves HB (1976) Neonatal behavior and nutrition-related mortality in domestic swine. J Anim Sci 42:235-241

Hemsworth PH, Winfield CG, Mullaney PD (1976) A study of the development of the teat order in piglets. Appl Anim Ethol 2:225-233

Herpin P, Le Dividich J (1995) Thermoregulation and the environment. In: Varley MA (ed) The neonatal pig: development and survival. CAB International, Oxford, pp 57-95 
Hofer H, East ML (1997) Skewed offspring sex ratios and sex composition of twin litters in Serengeti spotted hyaenas (Crocuta crocuta) are a consequence of siblicide. Appl Anim Behav Sci 51:307-316

Hudson R, Trillmich F (2007) Sibling competition and cooperation in mammals: challenges, developments and prospects. Behav Ecol Sociobiol DOI 10.1007/s00265-007-0417-z

Illmann G, Schrader L, Spinka M, Sustr P (2002) Acoustical mother-offspring recognition in pigs (Sus scrofa domestica). Behaviour 139:487-505

Jennions MD, Macdonald DW (1994) Cooperative breeding in mammals. Trends Ecol Evol 9:89-93

Jensen P (1986) Observations on the maternal behaviour of free-ranging domestic pigs. Appl Anim Behav Sci 16:131-142

Jensen $P$ (1988) Maternal behaviour and mother-young interactions during lactation in free-ranging domestic pigs. Appl Anim Behav Sci 20:297-308

Jensen P, Recen B (1989) When to wean---observations from free-ranging domestic pigs. Appl Anim Behav Sci $23: 49-60$

Jensen P, Gustafsson M, Augustsson H (1998) Teat massage after milk ingestion in domestic piglets: an example of honest begging? Anim Behav 55:779-786

Jeppesen LE (1982) Teat-order in groups of piglets reared on an artificial sow. I. Formation of teat-order and influence of milk yield on teat preference. Appl Anim Ethol 8:335-345

Kilner R, Johnstone RA (1997) Begging the question: are offspring solicitation behaviours signals of need? Trends Ecol Evol 12:11-15

Lack D (1947) The significance of clutch size. Ibis 89:302

Leece JG (1971) Rearing neonatal pigs of low birth weight with an automatic feeding device. J Anim Sci 33:47-51

Mauget R (1981) Behavioural and reproductive strategies in wild forms of Sus scrofa (European wild boar and feral pigs). In: Sybesma W (ed) The welfare of pigs. Martinus Nijhoff, The Hague, pp 3-15

Mauget R (1982) Seasonality of reproduction in the wild boar. In: Cole DJA, Foxcroft GR (eds) Control of pig reproduction. Butterworth Scientific, London, pp 509-526

Maynard Smith J (1994) Must reliable signals always be costly? Anim Behav 47:1115-1120

McBride G (1963) The "teat order" and communication in young pigs. Anim Behav II :53-56

Meyburg B (1974) Sibling aggression and mortality among nestling eagles. Ibis 116:224-228

Milligan BN, Fraser D, Kramer DL (2001) Birth weight variation in the domestic pig: effects on offspring survival, weight gain and suckling behaviour. Appl Anim Behav Sci 73:179-191

Mock DW (1984) Infanticide, siblicide and avian nestling mortality. In: Hausfater G, Blaffer Hrdy S (eds) Infanticide: comparative and evolutionary perspectives. Aldine Publishing Co., New York, pp 3-30 
Mock DW (1987) Siblicide, parent-offspring conflict, and unequal parental investment by egrets and herons. Behav Ecol Sociobiol 20:247-256

Mock DW (2004) More than kin and less than kind: the evolution of family conflict. The Belknap Press, Cambridge, MA

Mock DW, Parker GA (1998) Siblicide, family conflict and the evolutionary limits of selfishness. Anim Behav 56: 1-10

Mohr E (1960) Wilde Schweine. Verlag A, Ziemsen, Wittenberg Newberry RC, Wood-Gush DGM (1985) The suckling behaviour of domestic pigs in a semi-natural environment. Behaviour 95:11-25

Pajor EA (1998) Parent-offspring conflict and its implications for maternal housing systems in domestic pigs. Ph.D. thesis, McGill University, Montreal

Pajor EA, Weary DM, Caceres C, Fraser D, Kramer DL (2002) Alternative housing for sows and litters. Part 3. Effects of piglet diet quality and sow-controlled housing on performance and behaviour. Appl Anim Behav Sci 76:267-277

Peine JD, Farmer JA (1990) Wild hog management program at Great Smoky Mountains National Park. In: Davis LR, Marsh RE (eds) Proceedings of the 14th Vertebrate Pest Conference. University of Califomia, Davis, CA, pp 221-227

Pitts AD, Weary DM, Fraser D, Pajor EA, Kramer DL (2002) Alternative housing for sows and litters. Part 5. Individual differences in the maternal behaviour of sows. Appl Anim Behav Sci 76:291-306

Pope WF, Xie S, Broermann DM, Nephew KP (1990) Causes and consequences of early embryonic diversity in pigs. J Reprod Fertil (Suppl) 40:251-260

Pluske JR, William IH, Aherne FX (1995) Nutrition of the neonatal pig. In: Varley MA (ed) The neonatal pig: development and survival. CAB International, Oxford, pp 187-235

Rantzer D, Svendsen J, Westrom B (1995) Weaning of pigs raised in sow-controlled and in conventional housing systems. Part 2. Behaviour studies and cortisol levels. Swed J Agric Res 25:61-71

Rohde Parfet KA, Gonyou HW (1991) Attraction of newborn pigs to auditory, visual, olfactory and tactile stimuli. J Anim Sci 66:2165-2173

Scheel DE, Graves HB, Sherritt GW (1977) Nursing order, social dominance and growth in swine. J Anim Sci 45:219-229

Schneirla TC, Rosenblatt JS (1961) Behavioral organization and genesis of the social bond in insects and mammals. Am J Orthopsychiatr 31:223-253

Schnell JH (1958) Nestling behavior and food habits of Goshawks in the Sierra Nevada of California. Condor 60:377-403

Smale L, Holekamp KE, White PA (1999) Siblicide revisited in the spotted hyaena: does it conform to obligate or facultative models? Anim Behav 58:545-551

Spinka M, Algers B (1995) Functional view on udder massage after milk let-down in pigs. Appl Anim Behav Sci 43:197-212 
Svendsen J (1992) Perinatal mortality in pigs. Anim Reprod Sci 28:59-67

Thompson BK, Fraser D (1986) Variation in piglet weights: development of within-litter variation over a 5week lactation and effect of farrowing crate design. Can J Anim Sci 66:361-372

Thompson BK, Fraser D (1988) Variation in piglet weights: weight gains in the first days after birth and their relationship with later performance. Can J Anim Sci 68:581-590

Trillmich F, Wolf JBW (2007) Parent-offspring and sibling conflict in Galapagos fur seals and sea lions. Behav Ecol Sociobiol DOI 10.1007/s00265-007-0423-1

Trivers RL (1974) Parent-offspring conflict. Am Zool 14:249-264

Tuchscherer M, Puppe B, Tuchscherer A, Tiemann U (2000) Early identification of neonates at risk: traits of newborn piglets with respect to survival. Theriogenology 54:371-388

Varley MA (1995) Introduction. In: Varley MA ( ed) The neonatal pig: development and survival. CAB International, Oxford, pp 1-13

Weary DM, Fraser D (1995) Calling by domestic piglets: reliable signals of need? Anim Behav 50:10471055

Weary DM, Fraser D (1999) Partial tooth-clipping of suckling pigs: effects on neonatal competition and facial injuries. Appl Anim Behav Sci 65:21-27

Weary DM, Lawson G, Thompson BK (1996) Sows show stronger responses to isolation calls of piglets associated with greater levels of piglet need. Anim Behav 52:1247-1253

Weary DM, Pajor EA, Bonenfant M, Ross SK, Fraser D, Kramer DL (1999) Alternative housing for sows and litters: 2. Effects of a communal piglet area on pre- and post-weaning behaviour and performance. Appl Anim Behav Sci 65:123-135

Weary DM, Pajor EA, Bonenfant M, Fraser D, Kramer DL (2002) Alternative housing for sows and litters Part 4. Effects of sow-controlled housing combined with a communal piglet area on pre- and postweaning behaviour and performance. Appl Anim Behav Sci 76:279-290

White PA (2007) Maternal response to neonatal sibling conflict in the spotted hyena, Crocuta crocuta. Behav Ecol Sociobiol DOI 10.1007/s00265-007-0422-2

Whittemore CT, Fraser D (1974) The nursing and suckling behaviour of pigs. II. Vocalization of the sow in relation to suckling behaviour and milk ejection. Br Vet J 130:346-356

Zeuner FE (1963) A history of domesticated animals. Harper and Row, New York 